\title{
Investigation of Sox2, B-III Tubulin and Nestin Expressions in Neuropsheres Differentiated from Bovine Adipose Derived Mesenchymal Stem Cells by Immunofluorescence Staining
}

\author{
Özlem ÖZDEN AKKAYA ${ }^{*}$, Tayfun DİKMEN¹, Shah NAWAZ1 \\ 1 Afyon Kocatepe Universtiy, Faculty of Veterinary Medicine, Department of Histology and Embryology, 03200, Merkez, \\ Afyonkarahisar, Turkey
}

\begin{abstract}
Stem cell therapy can be an advantageous tool for non treatable diseases and has become a theme research for a better solution to many neurodegenerative cases. Despite of being very common in pet animals and equines in the field of veterinary medicine; stem cell based practises in bovines yet remain very limited. In the following study, Bovine adipose derived stem cells (BASCs) were isolated and differentiated into neurospheres. The potential expressions of neuron-specific markers $\beta$-III Tubulin, Nestin and Sox2 were demonstrated by immunofluorescence staining on these neurospheres. The outcomes of the study may provide a better understanding to the neurogenic potential of BASCs and can be a footstep for developing new therapeutical approaches for neurodegenerative diseases and syndroms in bovines.
\end{abstract}

Keywords: Adipose, Bovine, Nestin, Neurosphere, Sox2

Sığır Yağ Dokusundan İzole Edilen Mezenkimal Kök Hücrelerden Farklılaştırılan Nörosferlerde Sox2, ß-III Tubulin ve Nestin Ekspresyonlarının İmmunfloresan Boyama Yöntemi ile İncelenmesi

ÖZ

Kök hücre tedavisi, pek çok tedavisi olmayan hastalıkta olduğu gibi çoğu nörodejeneratif hastalık ve sendromda da daha iyi tedavi protokollerinin geliştirilmesi için önemli bir çalışma alanı haline gelmiştir. Kök hücrelerin klinik kullanımı pet hayvanları ve atlarda her ne kadar yaygınlaşmaya başlasa da sığırlarda kök hücre kullanımı hala oldukça sınırlıdır. Bu çalışmada sığır yağ dokusu kaynaklı mezenkimal kök hücreler izole edilmiş ve bu hücrelerden nörosfereldesi gerçekleştirilmiştir. Elde edilen nörosferlerin nöronspresifik belirteçler olan B-III Tubulin, Nestin ve Sox2 ekspresyonları immunfloresan boyama tekniği ile değerlendirilmiştir. Çalışmadan elde edilecek sonuçlar sığı yağ dokusu kaynaklı mezenkimal kök hücrelerin nörojenik potansiyelinin daha iyi anlaşılması açısından önemli olmakla birlikte bu sonuçlar sığırlarda nörojenik defektlerde kullanılabilecek potansiyel tedavi yaklaşımlarının geliştirilmesi hususunda da yol gösterici olacaktır.

Anahtar Kelimeler: Nestin, Nörosfer, Sığır, Sox2, Yağ Dokusu

To cite this article: Özden Akkaya Ö. Dikmen T. Nawaz. S. Investigation of Sox2, $\beta$-III Tubulin and Nestin Expressions in Neuropsheres Differentiated from Bovine Adipose Derived Mesenchymal Stem Cells by Immunofluorescence Staining. Kocatepe Vet J. (2019) 12(3):336-342

Submission: 20.07.2019 Accepted: 27.08.2019 Published Online: 29.08.2019

ORCID ID; ÖÖA: 0000-0001-6372-9155, TD: 0000-0003-4470-7465, SN: 0000-0001-5468-8267

*Corresponding author e-mail: ozlemozden@aku.edu.tr 


\section{INTRODUCTION}

Stem cell based therapies applied in human medicine, have gained equal importance in veterinary medicine during recent years, and are seen as a gleam of hope in the treatment of many diseases and syndromes. Today, treatment protocols and strategies using adult mesenchymal stem cells are applied in curing various diseases, especially locomotor system diseases, especially in horses and pet animals (Consiglio et al. 2011, Lange-Consiglio et al. 2013, Corradetti et al. 2014). Cellular therapies are accepted as a most promising and novel treatment approaches in treating neurological disorders. Neural stem cells $(\mathrm{NKH})$ are self-regenerating multipotent cells which could be obtained from embryo or fetal tissues only. The ethical constraints and difficulties to access the fetal tissues have directed the scientists to use adult stem cell. According to studies, the subgranular zone and subventricular zone (SVZ) in the central nervous system and olfactory neuroepithelial region in the nose are the sites for continued neurogenesis during adulthood (Brann and Firestein 2014). However, it is challenging to obtain neuronal stem cells from these regions particularly in adulthood for the purpose of cellular therapy. As a matter of fact mesenchymal stem cells derivatives from different tissues could be used to obtain the nerve cell or neurosphere. The neuro precursor cells present in the obtained neurospheres have ability to get differentiated into neurons, astrocytes or oligodendrocytes when cultured with appropriate media and conditions (Reynolds and Weiss 1992). Furthermore, precursor cells forming neurospheres can be applied directly in the treatment of neurodegenerative diseases of both humans and animals without differentiation (Girard et al. 2011).

Previous studies reported that fat tissue-derived mesenchymal stem cells obtained from humans and many other animal species can differentiate into neurospheres (Chung et al. 2013, Nagase et al. 2007, Radtke et al. 2009). According to literature and to our limited knowledge, no such study has been previously reported in bovines.

Bovine adipose derived stem cells (BASCs) represent a source of stem cells that express mesenchymal markers CD73 and CD90 while lacking expression of haematopoietic markers CD45 and CD34 (Cebo 2017, Da Silva et al. 2016). The studies reveal that BASCs are multipotent and can undergo osteogenic, adipogenic and chondrogenic differentiation (Sampaio et al. 2015, Da Silva et al. 2016). In another study it was suggested that BASCs are less immunogenic compared to bone marrow stem cells from the same specie because of low expression of MHC-I and MHC-II (Huaman et al. 2019). Stem cell or neurosphere applications in neurodegenerative diseases in cattle are thought to increase the chances of treatment success which is very limited in this field. The aim of this study was to characterize the adipose tissues derived neurospheres properties in bovines. The data of this study will guide the treatment of neurodegenerative diseases in cattle and the clinical applications of stem cells.

\section{MATERIALS and METHODS}

\section{Adipose derived stem cells isolation and culture}

The subdermal fat was collected from the freshly slaughtered animals with the help of sterile forceps and scissors and brought to laboratuary in sterile Hank's Balanced Salt Solution (HBSS Sigma, USA) containing 2\% Pen-Streptomycin (Gibco, UK). The samples were first washed with sterile Iodine solution and later on were washed with HBSS contaning $2 \%$ Pen-Streptomycin for three times to remove any contamination. The fat tissues samples were transferred to $50 \mathrm{ml}$ centrifuge tubes and fat was mechanically dissected to fine samples being exposed to enzymatic digestion using Collagenase II (Sigma, USA) $(1 \mathrm{mg} / \mathrm{ml}-0.1 \%)$ at $37^{\circ} \mathrm{C}$ for 1 hour. The sample after digestion was strained using $100 \mu \mathrm{m}$ cell strainer. The strained digested fat tissues were then centrifuged at $250 \mathrm{~g}$ for 10 minutes. By discarding the supernatant, the pellet was dissolved in MEM (Sigma, USA) containing 10\% FBS and cultured in $25 \mathrm{~cm}^{2}$ flasks at $37^{\circ} \mathrm{C}$ and $5 \% \quad \mathrm{CO} 2$ incubator for proliferation. The media was changed every $3^{\text {rd }}$ day and cells were passaged upon $70-80 \%$ confluence.

\section{Neurospheres generation}

BASCs from late passages were collected and plated at a culture density of $5 \times 10^{4}$ cells $/ \mathrm{cm}^{2}$ on $0.01 \%$ poly-L-Lysine (Sigma, USA) coated 4-well plates. DMEM/F-12 (Gibco, UK), containing 1\% Insulintransferrin-selenium (ITS) (Gibco, USA), $50 \mathrm{ng} / \mathrm{mL}$ EGF (Sigma, USA), and 50ng/mL FGF (R\&D System, USA) was used as neuropsheres culture medium. The cells were allowed to get differentiated in neuropsheres under optimal conditions. To prevent the nutrient depletion, the half of the medium was changed every $2^{\text {nd }}$ day. The BASCs started differentiating into neurospheres after $48 \mathrm{~h}$ (Bez et al. 2003).

\section{Neurospheres Collection and Immunofluorescence}

Neuropsheres were stained for particular markers by Immunofluorescence studies as described by Sasaki et al. (2010). A pool of neurospheres was developed $48 \mathrm{~h}$ post differentiation and washed with PBST (Phosphate buffer saline containing 0.1\% Tween 20 (BioRad, USA) three times for $5 \mathrm{~min}$ each. Later the cells were fixed with $4 \%$ paraformaldehyde in PBS $(\mathrm{pH}$ 7.4) for $10 \mathrm{~min}$ at room temperature. After fixation, the neuropsheres were again washed with ice-cold PBS for three times 5 minutes each. The permeability step was performed with PBS containing 
0.1\% Triton X-100 (MP Biomedicals-France). After washing with PBST, the blocking was carried using $10 \%$ serum from the species in which the secondary antibodies were raised. The primary antibodies; antiNestin (1:250 Goat polyclonal; Santa Cruz-sc21248), anti- $\beta$-III Tubulin (1:300 Mouse monoclonal; Abcamab78078) and anti-Sox2 (1:50 Rabbit polyclonal; Abcam- ab5603)used in this study were diluted in 1\% BSA in PBST. The secondary antibodies consisted of Donkey anti Goat Alexafluor conjugated (1:250; Abcam-ab150137), Goat anti Mouse Texas Red conjugated (1:100; Abcam-ab6787) and Goat anti Rabbit Alexafluor conjugated (1:200; Abcamab150077) respectively diluted in 1\% BSA.

\section{Osteogenic Differentiation}

BASCs were collected after $3^{\text {rd }}$ passage and the cells were seeded into 4-well plates at a density of 9,000 cells $/ \mathrm{cm}^{2}$ in growth media. After the cells reached the confluence, the induction media which consisted of 10\% FBS (Biowest, South America), 1\% penicillinstreptomycin (Gibco, UK), 0.1\% amphoterisin-B (Biowest, France), $50 \mu \mathrm{g} / \mathrm{ml}$ L-ascorbic acid (Sigma, USA), $10 \mathrm{mM} \beta$-glycerophosphate (Gibco, UK), 0.01 $\mu \mathrm{M}$ dexamethasone (Sigma, USA) in $\alpha$-MEM (Lonza, Belgium). The media was changed in every 3 days and the osteogenic differentiation was performed till 21 days. The osteogenic differantiation was demonstrated by Alizarin Red S staining.

\begin{abstract}
Alizarin Red S Staining
For demonstrating calcium deposits as a result of osteogenic differentiation; Alizarin Red S staining was performed. For staining, the culture media was discarded and cells were washed with Hank's Balanced Salt Solution (HBSS, Sigma, USA). Then cells were fixed by 4\% paraformaldehyde (Merck, Germany). After fixation, the paraformaldehyde was discarded and cells were washed with distilled water. Afterwards, cells were stained with $80 \mathrm{mM}$ Alizarin Red S ( $\mathrm{pH}$ 4.2) (Merck, Germany) in deionized distilled water for 30 minutes. After 30 minutes the staining solution was washed carefully and plates were observed under inverted microscope. The calcium deposits were observed as orange-red stains.
\end{abstract}

\section{Adipogenic Differentiation}

After $3^{\text {rd }}$ passage, BASCs were seeded into 4-well plates at a density of 9,000 cells $/ \mathrm{cm}^{2}$. Cells were cultured in growth media till they reached confluence. After reaching confluence, cells were cultured with adipogenic induction media (AIM) and adipogenic maintanence media (AMM) for 21 days. The AMM was only used at $7^{\text {th }}$ and $15^{\text {th }}$ days of differentiation in order to maintain adipogenesis while the AIM was used in the rest of the study. The AIM consisted of 10\% FBS (Biowest, Soauth America), 1\% penstreptomycin (Gibco, UK), 0.1\% amphotericin-B (Biowest, France), $1 \mu \mathrm{M}$ dexamethasone (Sigma, Belgium), $500 \quad \mu \mathrm{M} 3$-Isobutyl-1-methylxanthine
(IBMX, Sigma, Germany) $10 \mu \mathrm{g} / \mathrm{mL}$ insulin (Sigma) in MEM. On the other hand AMM consisted of $10 \%$ FBS (Biowest, South Merica), 1\% penicillinstreptomycin (Gibco, UK) and $10 \mu \mathrm{g} / \mathrm{mL}$ insulin in MEM. After 21 days, Oil Red $\mathrm{O}$ staining was performed in order to demonstrate oil droplets.

\section{Oil Red O Staining}

After 21 days of differentiation, the differentiation media was discarded and cells were washed first with PBS then with 70\% ethanol. Afterwards the cells were fixed with 10\% buffered neutral formaline for 20 minutes. Then formaline was discarded and cells were washed with PBS and with 70\% ethanol once more. After washing the cells, Oil Red $\mathrm{O}$ stain was applied for 25 minutes. The stock solution for Oil Red O (12 mM Oil Red O (Sigma-Aldrich, USA) in isopropyle alcohol was diluted with deionized distilled water in 2/3 ratio to be used in staining procedure. After 25 minutes, staining solution was discarded and cells were washed first with $70 \%$ ethanol and then with deionized distilled water. A cross staining was done by Harris' Hematoxylin for nuclear staining.

\section{RESULTS and DISCUSSION}

The fibroblast like plastic adherent cells were isolated and proliferated for few passages (Figure 1). The stem cells started making colonies 4-5 days post culture. The cells from P0 reached at confluence in around 11- 13 days. The cells from all different animals expressed same morphology as the tissues were isolated from male animals of same age. BASCs designate the class of cells that could be easily isolated and propagated (Chung et al. 2012). In order to counter any changes we preffered isolating the cells from same age group and from male sex only. The cells exhibited the fibroblastic morphology, easily reached to confluence which was consistent with previous studies (Sampaio et al. 2015, Da Silva et al. 2016). Chung et al. (2012) reported that adipose tissue are among the main sources of MSC in veterinary medicine and have advantage of faster growth in invitro conditions compared to counterpart bone marrow stem cells.

BASCs were formerly announced to have the capacity to differentiate into osteocytes and adipocytes. BASCs showed multipotent properties as they were able to differentiate into both osteogenic and adipogenic lineages (Sampaio et al. 2015, Da Silva et al. 2016). Similar to previous studies, we were successfully able to differentiate BASCs into adipogenic and ostegenic lineages. The adipogenic differentiation was evaluated by Oil Red $\mathrm{O}$ staining. After the staining, oil droplets were visible in red-pink color under the microscope (Fig. 2 A,B). The osteogenic differentiation was demonstrated by Alizarin Red S staining. After the Alizarin Red S staining, osteogenic differentiation was investigated 
under microscope. The red-orange stained calcium deposits comfirmed the osteogenic differentiation (Fig, 2 C,D).

Under the effect of optimal concentration of epidermal growth factor (EGF) and fibroblast growth factor (FGF), potent BASCs were observed to be suspended in a serum free medium while undergoing differentiation. This neurogenic differentiation media allowed the BASCs to get transformed into the characteristic 3-D clusters called neurospheres which were consistent to previous studies performed on MSCs. Similar to our study, Hu et al. (2013) reported that EGF and bFGF supplementation to medium promoted neural lineage differentiation in adipose stem cells and impaired their mesodermal differentiation ability.

Variations were observed in the sizes of neuropsheres and morphology varied from round to oval. Unfortunately we couldn't record the difference in neurosphere numbers, size and shape variations with advanced passage number. However, neurospheres were observed to be increased in size 3-4 days post generation. The neurospheres remained intact even at 6-7 days post differentiation. We also observed that variations in cell density and variable concentrations of growth factors in the median affected the generation of neuropsheres. We noticed that the concentration of EGF and FGF actually mattered the most. At as low concentrations of EGF and FGF, as $20 \mathrm{ng} / \mathrm{ml}$, BASCs lacked the tendency to form the characteristic neuropsheres. Hu et al. (2013) reported the similar results. It was observed that at an opitimal cell density of 90,000 cells $/ \mathrm{cm}^{2}$ and at concentration of $50 \mathrm{ng} / \mathrm{ml}$ for EGF and FGF the BASCs started differentiating into neurospheres at 24 hours (Figure 3).

The immunofluroscence staining results showed that the neurospheres strongly express neuron specific markers $\beta$-III Tubulin, Nestin and Sox 2 as shown in the figure (Figure 4). Similar to other studies that have been reported so far, we found that nearly all constituent cells of originated neurospheres were immunoreactive for neural intermediate filament Nestin, proneuronal neurofilament marker $\beta$-III Tubulin and transcription factor Sox 2 (Reynolds and Weiss 1992, Brazel et al. 2005). The expression of Sox2 and generation of varying mature cell types, including neurons, astrocytes, and oligodendrocytes, proves the legitmate multipotency of neuropsheres. Studies report that all neurospheres contain cells at multiple stages of differentiation, including stem cells, which are capable to proliferate into neural progenitor cells, postmitotic neurons, and glial cells (Theocharatos et al. 2013). Moreover, the heterogeneity of the neurosphere increases with its size, since more and varied cell types arise with a longer time in culture (Jensen and Parmar 2006).

Summarising the neurospheres differentiation and the potent neural markers expression, we assume that BASCs have the great potential to generate neuropsheres and could be used to treat the peripheral nerve injuries in veterinary profession.
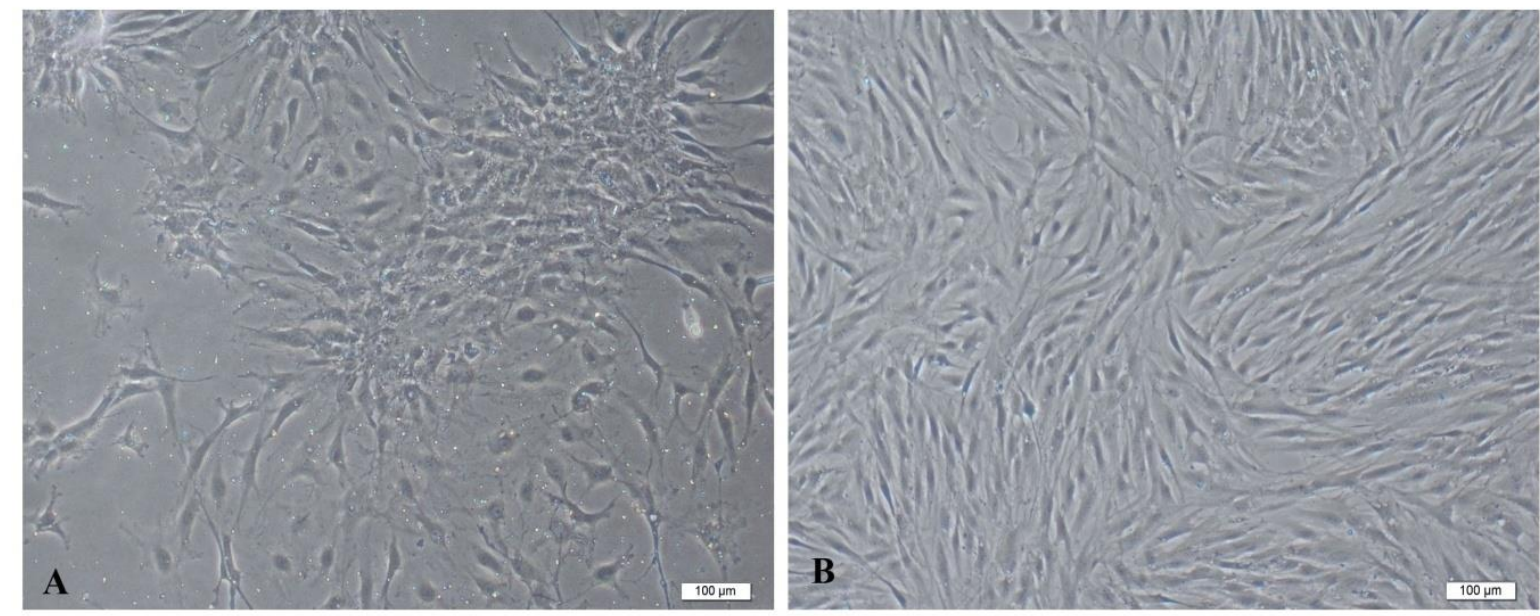

Figure 1. Fibroblast-like morphology of BASCs at different passages. A: P0, B: P3; Bar $=100 \mu \mathrm{m}$. 

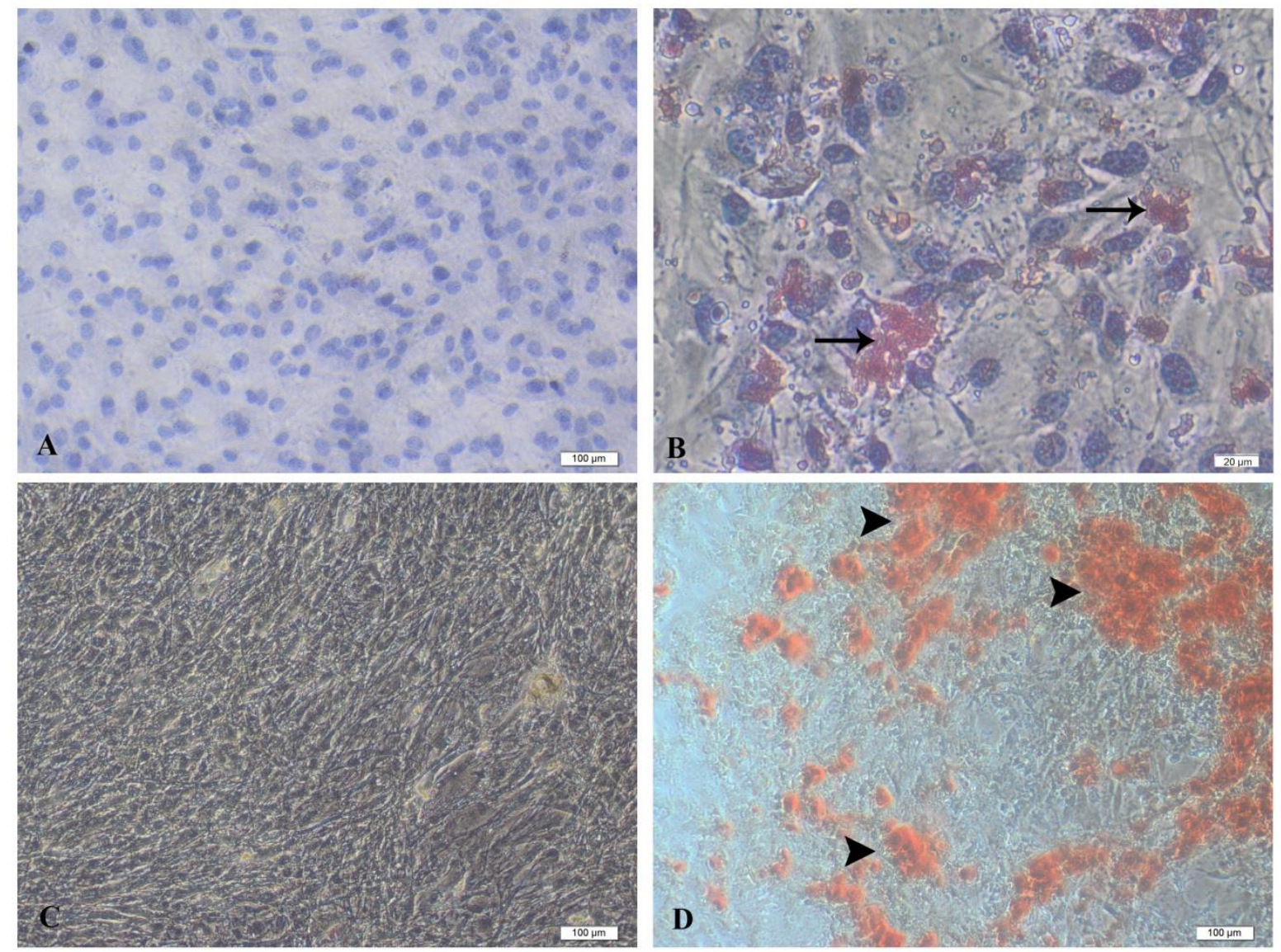

Figure 2. Demonstration of osteogenic and adipogenic differentiations of BASCs. A,B: Adipogenic differentiation. A: Control group, Bar $=100 \mu \mathrm{m}$. B: experiment group, arrows: red stained oil droplets. Bar $=20 \mu \mathrm{m}$. C,D: Osteogenic differentiation. C: Control group, Bar=100 $\mu \mathrm{m}$. D: Experiment group, arrow heads: Orange-red stained calcium deposits. Bar $=100 \mu \mathrm{m}$.
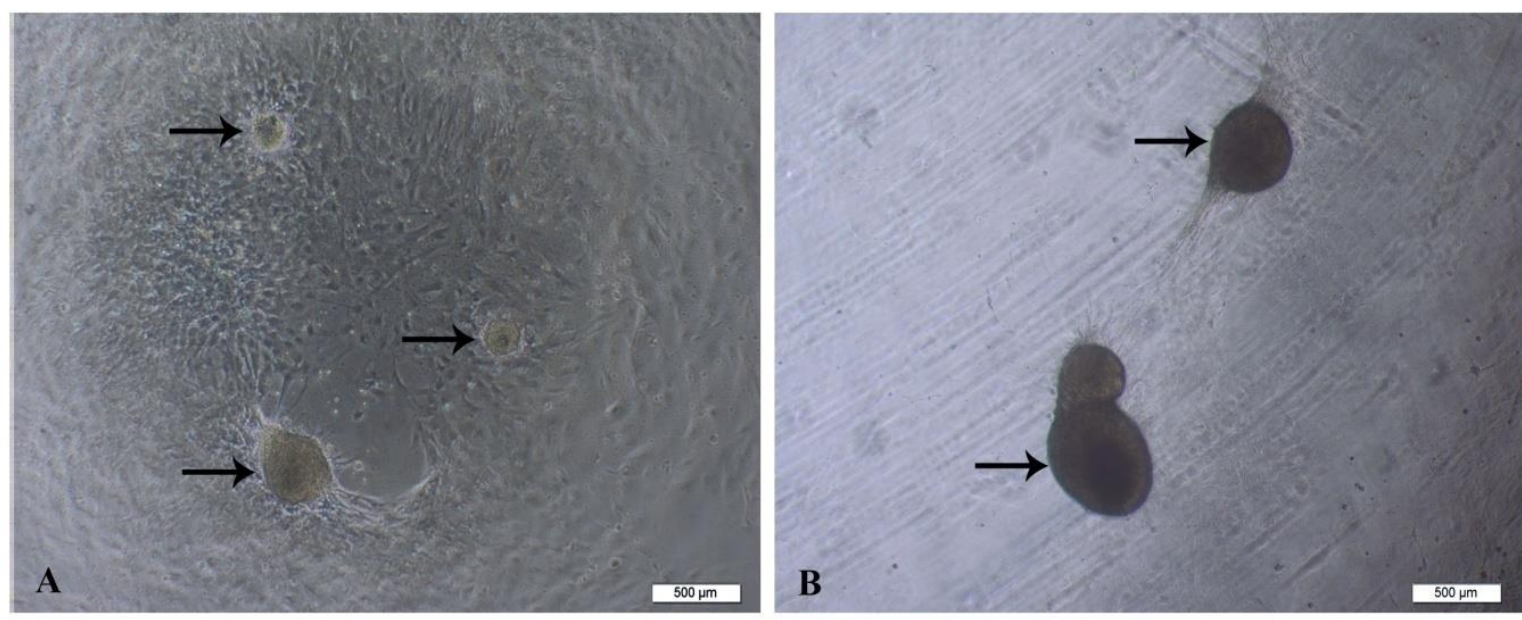

Figure 3. Neurospheres at different time intervals. A: $24^{\text {th }}$ hour; B: $48^{\text {th }}$ hour. Bar $=500 \mu \mathrm{m}$. 
DAPI

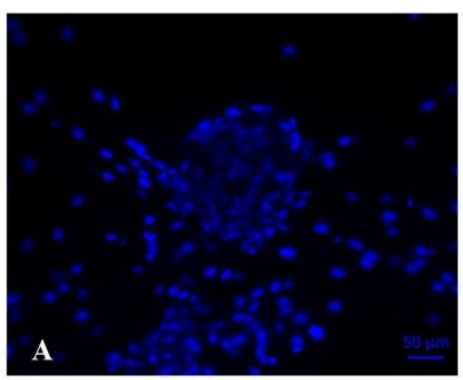

DAPI

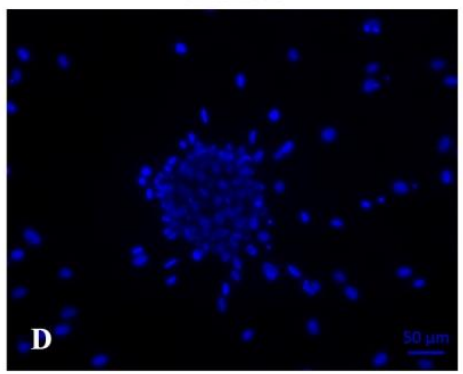

DAPI

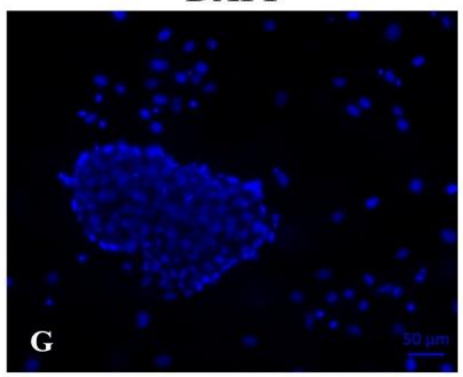

Sox 2

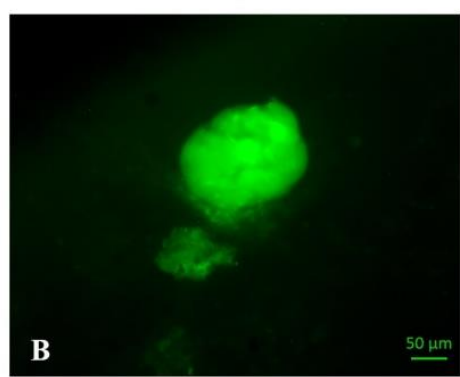

Nestin

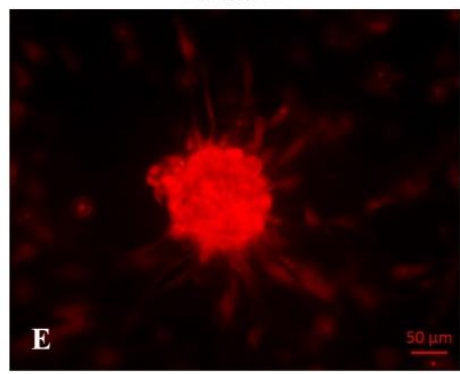

B-III Tubulin

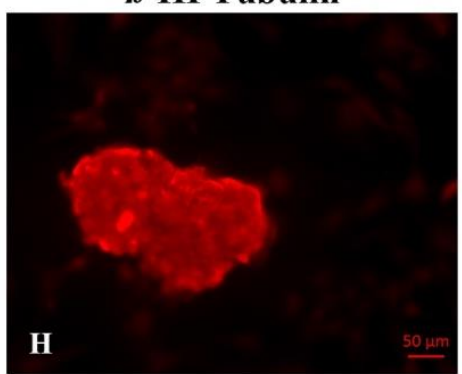

Merged
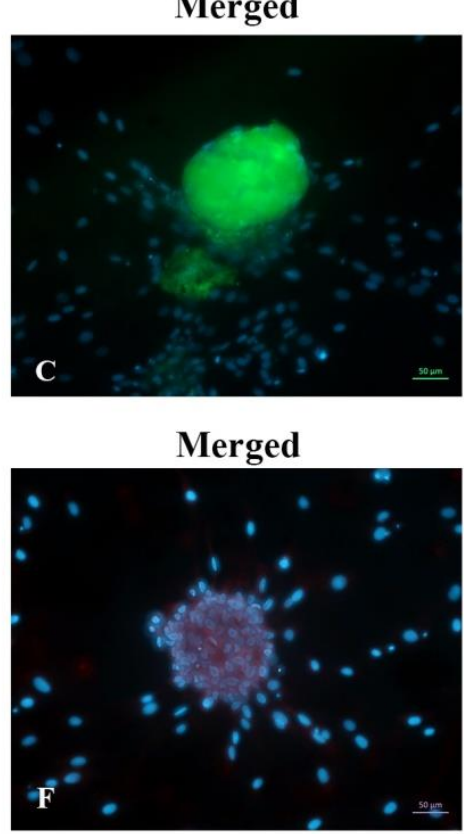

Merged

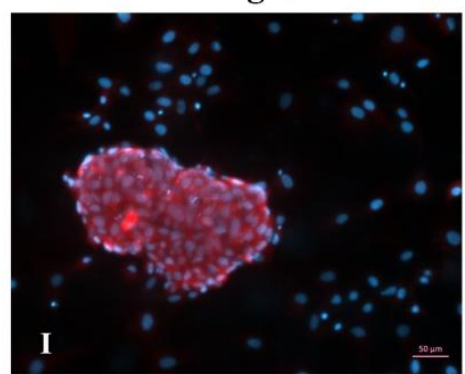

Figure 4. Immunofluoroscence staining on BASCs derived neurospheres. A, D, G: DAPI; B: AntiSox2, E: Anti-Nestin, H: Anti-ß-III Tubulin, C,F,I: Merged images.

\section{CONCLUSION}

The study showed that BASCs are able to differentiate into capable neurospheres which express at least Nestin, Sox 2 and $\beta$-III Tubulin. Although the study showed the neurospheres of BASCs are indeed having important qualities for neurogenesis, the cells should be further investigated for their neuronal character and their neural differentiation potentials by checking other markers such as GFAP, Pax6 etc both with mRNA and protein levels. In addition for the peculiar application functions for regenerative therapies, neurosphere culture system could be a valuable source to study in vitro neurogenesis and neural development in bovines. Since the BASCs express low MHC I and MHC II expression so we can assume that neurospheres harvested from adipose tissues obtained from slaughtered animals could be less immunogenic and may be opted for allogenic studies.

\section{ACKNOWLEDGEMENT}

All procedures were approved by the Ethical Committee of Afyon Kocatepe University, Turkey (AKÜHADYEK-5119; 30.04.2019).

\section{REFERENCES}

Bez A, Corsini E, Curti D, Biggiogera M, Colombo A, Nicosia RF, S. F. Pagano SF, Parati EA. Neurosphere and neurosphere-forming cells: morphological and ultrastructural characterization. Brain Res. 2003; 993 (12):18-29.

Brann JH, Firestein SJ. A lifetime of neurogenesis in the olfactory system. Front Neurosci 2014; 8:182.

Brazel CY, Limke TL, Osborne JK, Miura T, Cai J, Pevny L, Rao MS. Sox2 expression defines a heterogeneous population of neurosphere-forming cells in the adult murine brain. Aging Cell. 2005; 4(4):197-207.

Cebo, D. Characterization Of Bovine Adipose-Derived Stem Cells. IJSTR 2017; 6 (5):16-18.

Chung CS, Fujita N, Kawahara N, Yui S, Nam E, Nishimura R. A comparison of neurosphere differentiation potential of canine bone marrow-derived mesenchymal stem cells and adipose-derived mesenchymal stem cells. J Vet Med Sci. 2013; 75(7): 879886.

Chung DJ, K. Hayashi K, Toupadakis CA, Wong A, Yellowley CE. Osteogenic proliferation and differentiation of canine bone marrow and adipose tissue derived mesenchymal stromal cells and the influence of hypoxia. Res Vet Sci. 2012; 92 (1):66-75.

Consiglio AL, Tassan S, Corradetti B, Bizzaro D, Bignotti A, Cremonesi F. 2011. Amniotic mesenchymal-derived 
cells for the treatment of tendinopathy in the horse: first report. Ippologia. 2011; 22(3):13-28.

Corradetti B, Correani A, Romaldini A, Marini MG, Bizzaro D, Perrini C, Cremonesi F, Lange-Consiglio A. Amniotic membrane-derived mesenchymal cells and their conditioned media: potential candidates for uterine regenerative therapy in the horse. PloS one 2014; 9(10):e111324.

Da Silva, CG, Martins CF, Cardoso TC, Da Cunha ER, Bessler HC, Martins GHL, Pivato I, Báo SN. Production of bovine embryos and calves cloned by nuclear transfer using mesenchymal stem cells from amniotic fluid and adipose tissue. Cell Reprogram 2016; 18 (2):127-136.

Girard SD, Devéze A, Nivet E, Gepner B, Roman FS, Féron F. Isolating nasal olfactory stem cells from rodents or humans. JoVE. 2011;1 (54):e2762.

Hu F, Wang X, Liang G, Lv L, Zhu Y, Sun B, Xiao Z. Effects of epidermal growth factor and basic fibroblast growth factor on the proliferation and osteogenic and neural differentiation of adipose-derived stem cells. Cell Reprogram. 2013: 15 (3):224-232.

Huaman O, Bahamonde J, Cahuascanco B, Jervis M, Palomino J, Torres CG, Peralta OA. Immunomodulatory and immunogenic properties of mesenchymal stem cells derived from bovine fetal bone marrow and adipose tissue. Res Vet Sci. 2019; 124:212222

Jensen JB, Parmar M. Strengths and limitations of the neurosphere culture system. Mol Neurobiol. 2006; 34 (3):153-161.

Lange-Consiglio A, Tassan S, Corradetti B, Meucci A, Perego R, Bizzaro D, Cremonesi F. Investigating the efficacy of amnion-derived compared with bone marrowderived mesenchymal stromal cells in equine tendon and ligament injuries. Cytotherapy 2013; 15 (8):1011-1020.

Nagase T, D. Matsumoto D, Nagase M, Yoshimura $K$, Shigeura $T$, Inoue $M$, Hasegawa $M$, Yamagishi $M$, Machida M. Neurospheres from human adipose tissue transplanted into cultured mouse embryos can contribute to craniofacial morphogenesis: a preliminary report. J Craniofac Surg. 2007; 18 (1):49-53.

Radtke C, Schmitz B, Spies M, Kocsis J, Vogt P. Peripheral glial cell differentiation from neurospheres derived from adipose mesenchymal stem cells. Int J Dev Neurosci. 2009; 27 (8):817-823.

Reynolds BA, Weiss S. Generation of neurons and astrocytes from isolated cells of the adult mammalian central nervous system. Science 1992; 255 (5052):1707-1710.

Sampaio RV, Chiaratti MR, Santos D, Bressan FF, Sangalli JR, d. Sá ALA, Silva T, Costa N, Cordeiro M, Santos S. Generation of bovine (Bos indicus) and buffalo (Bubalus bubalis) adipose tissue derived stem cells: isolation, characterization, and multipotentiality. Genet Mol Res. 2015; 14 (1):53-62.

Sasaki R, Aoki S, Yamato M, Uchiyama H, Wada K, Ogiuchi H, Okano T, Ando T. A protocol for immunofluorescence staining of floating neurospheres. Neurosci Lett 2010; 479 (2):126-127.

Theocharatos S, Wilkinson DJ, Darling S, Wilm B, Kenny SE, Edgar D. Regulation of progenitor cell proliferation and neuronal differentiation in enteric nervous system neurospheres. PloS one 2013; 8 (1):e54809. 